\title{
Coulisses
}

Revue de théâtre

25| Hiver 2002

Varia

\section{Sélection bibliographique}

\section{(2) OpenEdition}

1 Journals

Édition électronique

URL : http://journals.openedition.org/coulisses/6137

DOI : $10.4000 /$ coulisses. 6137

ISSN : 2546-9460

\section{Éditeur}

Presses universitaires de Franche-Comté

\section{Édition imprimée}

Date de publication : 1 janvier 2002

Pagination : 129

ISBN : 2-84627-052-X

ISSN : $1150-594 X$

\section{Référence électronique}

« Sélection bibliographique », Coulisses [En ligne], 25 | Hiver 2002, mis en ligne le 24 octobre 2019, consulté le 15 novembre 2019. URL : http://journals.openedition.org/coulisses/6137

Ce document a été généré automatiquement le 15 novembre 2019.

Coulisses 


\section{Sélection bibliographique}

\section{Euvres}

A. Gatti : Euvres théâtrales (3 tomes), Ed. Verdier 1999

A. Gatti : La Parole errante, Ed. Verdier 1999

A. Gatti : Les incertitudes de Werner Heisenberg, feuilles de brouillon pour cueillir les larmes des cathédrales dans la tempête et dire Jean Cavaillès sur une aire de jeu. Ed. Métropolis, Genève, juillet 1999

A. Gatti: Incertitudes de la mécanique quantique devenant chant des oiseaux du Graal pour l'entrée des groupes (de Galois) dans le langage dramatique. Cahiers de Coulisses $n^{\circ} 2$, Juin 2001

\section{Sur A. Gatti}

Armand Gatti et Marc Kravetz, L'aventure de la Parole errante, L'éther vague - La Parole errante, 1987

Armand Gatti et Claude Faber, La poésie de l'étoile, paroles texte et parcours, Éditions Descartes, 1997 